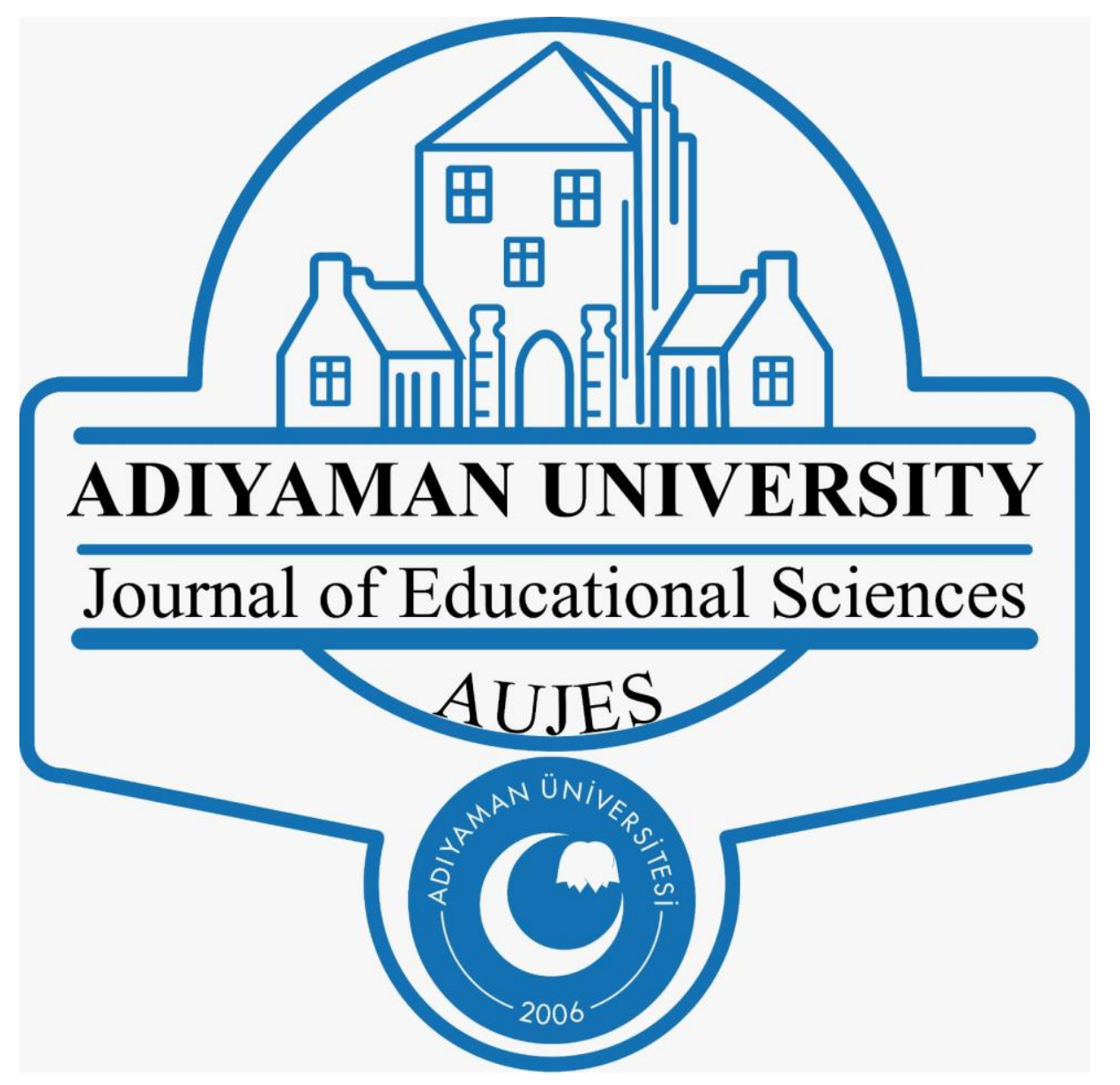

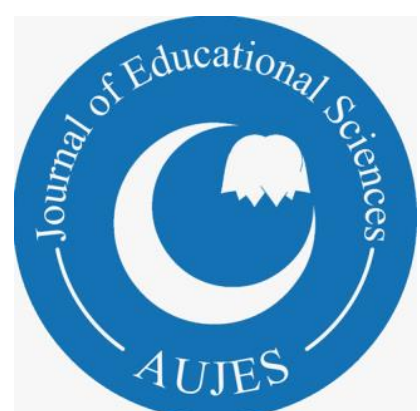

ADIYAMAN UNIVERSITY Journal of Educational Sciences (AUJES)
An Analysis of the Curriculum and Instruction Departments in Turkey and the Postgraduate Theses Written in this Branch from various Aspects

Memet KARAKUŞS ${ }^{1}$, Nihan ARSLAN NAMLI ${ }^{2}$, Ali Kemal UĞUR ${ }^{3,}$ Nilgün SAKAR $^{4,}$ Seray DOĞRU ORAL ${ }^{5,}$

\footnotetext{
${ }^{1}$ Assoc. Prof., Çukurova University. Adana

${ }^{2}$ Lecturer, Iskenderun Technical University, Hatay

${ }^{3}$ Lecturer Çukurova University, Adana

${ }^{4}$ Teacher, Ministry of National Education, Niğde

${ }^{5}$ Teacher, Ministry of National Education, Hatay
} 
Karakuş, Arslan Naml, Uğur, Sakar, Doğru Aral

\section{To cite this article:}

Karakuş, M., N, Arslan Namlı., A, Uğur., N, Sakar.,\& S, Doğru Aral. (2020). An Analysis of the Curriculum and Instruction Departments in Turkey and the Postgraduate Theses Written in this Branch from various Aspects. Adiyaman Univesity Journal of Educational Sciences, 10(1), Page 1-19. 


\title{
An Analysis of the Curriculum and Instruction Departments in Turkey and the Postgraduate Theses Written in this Branch from various Aspects
}

\author{
Memet KARAKUŞ ${ }^{1}$,Nihan ARSLAN NAMLI ${ }^{2 *}$, Ali Kemal UĞUR ${ }^{3}$, Nilgün SAKAR ${ }^{4}$, Seray DOĞRU \\ ORAL $^{5}$ \\ ${ }^{1}$ Assoc. Prof., .Çukurova University. Adana \\ ${ }^{2}$ Lecturer, Iskenderun Technical University, Hatay \\ ${ }^{3}$ Lecturer Çukurova University, Adana \\ ${ }^{4}$ Teacher, Ministry of National Education, Niğde \\ ${ }^{5}$ Teacher, Ministry of National Education, Hatay
}

\begin{abstract}
The aim of this study is to analyze the Curriculum and Instruction offering postgraduate education in Turkey and the subjects of postgraduate and doctorate dissertations written in this field between 1974 and 2017. The lectures given in 28 universities with postgraduate and doctorate programs, the academic personnel, and the terms of acceptance to and graduation from the postgraduate education were taken into consideration. Written until 2017, totally 1599 theses (1162 postgraduate theses and 437 doctorate dissertations) were examined. Among 28 universities, the ones employing highest number of academic personnel were determined to be Gazi, Middle East Technical, and Hacettepe Universities. The most frequently offered courses were found to be related with "Curriculum Development" and "Curriculum Assessment". The general average of score required to pass to these phase was determined to be minimum 2.00 for postgraduate and 2.50 for doctorate. Examining the theses from the aspects of themes, it was determined that the fields, on which the theses were written most frequently, were "Curriculum", "Approach, strategy, and method", "Attitude and value education", and "Thinking Education and Learning Strategies". Based on the study results, it is recommended to carry out the qualitative studies on this subject on a wider sample.
\end{abstract}

Key words: Curricula and education, Postgraduate education, Higher education

\section{Introduction}

The knowledge accumulation forming as a result of the researches of humans on exploring the nature and increasing the quality of life contributes to the progression for each new generation. Against the society's necessities becoming complex and hard-to-meet in the course of time, the schools and the education system implemented in these schools have been developed as a way of conveying the knowledge in a regular manner (Senemoğlu, 1991). The education system runs based on a process. As in the world, this process covers mainly three levels in Turkey as basic education, secondary education, and higher education.

According to the Fundamental Law Nr.1739 on National Education, which is accepted to be the most comprehensive law guiding the Turkish education system, the elementary education is the level of education, in which the fundamental knowledge, skills, attitudes, and habits for being a good citizen are taught and it is aimed to prepare the students for the life and higher education in parallel with their interests, skills, and capabilities. The secondary education is the level of education, in which the students are given a common culture and it is aimed to provide them with the consciousness of realizing the personal and social problems, seeking after the solution options, and contributing to the social and cultural development of the country. The higher education, however, is the level of education, in which the educational activities are executed in order to educate the students in parallel with their interests, skills, and capabilities and in accordance with the scientific policy and human resource necessities of society at higher levels, to execute scientific education at various levels, to carry out the studies and researches on advancing in the science for solving the scientific, technical, and cultural problems, and to publish all kinds of publications enabling the progression of science and technics.

Since the University Reform in 1981, the higher education has been affiliated to Higher Education Board (YÖK). Based on the Law Nr.2547 on Higher Education in 1981, a re-structuring process was initiated from academic, institutional, and administrative aspects. In this law, all the higher education institutions of our

\footnotetext{
* Corresponding Author: Nihan ARSLAN NAMLI, nihan.arslannamli@iste.edu.tr
} 
country were collected under the shelter of YÖK, academies were transformed into universities, education institutes were transformed into education faculties, and the conservatories and vocational high schools were affiliated to universities. Thus, YÖK having its autonomy and public legal personality within the frame of responsibilities and authorities given by the provisions of aforementioned law and Art.130 and 131 of Constitution became the only body that is responsible for all of the higher education (http://www.yok.gov.tr/web/guest/tarihce).

The higher education is defined as the "whole of universities, which maintain, spread, and improve the scientific knowledge and in which the scientific researches are conducted, and all the institutions affiliated to these universities" (Birinci, 1996). Accordingly, the aim of higher education is to educate the students in parallel with their skills, interests, and capabilities in accordance with the scientific policy and human resource necessities of the country at various levels, to carry out scientific researches, to publish any publication ensuring the advancement in science and expressing the results of researches/analyses, to report the results of researches and analyses requested by the government, and to spread the date, which will improve the general level and shed light to the path of Turkish society, in written and verbal forms to the society (Art. 4 of Law Nr.2547 on Higher Education, 1981).

The legal foundation of undergraduate education in Turkey is based on Law Nr.2547 on Higher Education. According to Art. 3/t of this law, the postgraduate education is divided into departments of postgraduate, doctorate, specialization in medicine, and proficiency in art (Law of Higher Education, 1981). The postgraduate education is the planned education aiming to educate scientists to contribute to the progression of science through the researches, education of next generations, and development of the country (Özden and Ergin, 2013). There are many factors playing role in the increase seen in the importance of postgraduate education laying the foundation of modern universities defined in Constitute of 1982. Some of these factors are the execution of research activities in the universities, role of universities in rapid advancement of technology, increase in the schooling in higher education, and the need for highly qualified human resource required for the researches on country's problems and also needed for the development of country (Karakütük, 2002). The general purpose of postgraduate education is the activities carried out at postgraduate levels in universities, and the objectives are to educate scientists and academic personnel to meet the needs of society and to contribute the knowledge, to be respectful to the ethical values, to examine the scientific events from a comprehensive and deep perspective, and to be able to carry out researches independently (Varış, 1972; Tuzcu, 2003). The Council of Turkish Academy of Sciences defined the function of postgraduate education as producing and spreading the science and art, to provide solution proposals for the social problems by realizing them, and to contribute to the education of qualified human power (TÜBA, 2001, 56).

One of the postgraduate programs related with education-instruction is the department of Curriculum and Instruction. Together with the curriculum concept being discussed from aspects of social dynamism on one side and a wider perspective including the student life on the other side, this discipline started to be added into programs of universities under the title of "Curricula and Education" in various countries, firstly in USA, since 1950s, and it keeps its place (Varış, 1989). In Turkey, the Department of Curriculum and Instruction was established in 1965 in Ankara University in 1965 for the first time in order to fulfill the responsibilities and achieve the objectives of faculty of education (Gözütok, 1994). YÖK completed the comprehensive organization of these programs in 1983. Even though it varies between the faculties, the Education Management and Audit, Education Management and Planning, Special Education, Measurement and Assessment in Education, psychological counseling and guidance, and Curriculum and Instruction were accepted as the branches of educational sciences. They were put into practice in educational year of 1983-1984. As of the year 1989, as a result of the organization movement in higher education, the undergraduate programs of Curriculum and Instruction were stopped except Psychological Counseling and Guidance program and the postgraduate education have been continuing in this discipline (Mıhçıŏlu, 1989).

The objective of postgraduate education in Curriculum and Instruction discipline varies between the universities. However, it can be stated that the general objectives are to educate graduates having the skills, attitudes, and capabilities required for designing the educational programs, offering guidance in implementation and assessment, specialized in designing the educational programs, and improving the educational process, and the universities seem to share the similar objectives regarding the competencies of graduates (Kaya, 2014).

In order for Curriculum and Instruction department to maintain its existence, it is very important for this discipline to keep itself updated in parallel with the social, cultural, economic, and political dynamics of the world. This discipline, which undertook significant responsibilities in further improving the quality of educational system, should assess its own curricula first in order to fulfill its functions (Yapıcioğlu, Kara and Sever, 2015). As in all other disciplines, the postgraduate dissertations written in Curriculum and Instruction discipline significantly contribute to the development of this field as a scientific discipline (Bikmaz, Aksoy, Tatar and Altnnyüzük, 2013). The development of academic disciplines is closely related with the literature 
reviews. It can be seen that the number of literature reviews increased in all the academic fields. Making a general evaluation of researches in educational sciences in certain periods not only provides the information about the quality of studies carried out in that period but it also shed light to the future studies (Erdem, 2011). The analyses of previous researches guide the ones, who aims to carry out a study on that field, by showing what have been done or not in that field (Cohen, Manion, \& Morrison, 2007). The trends of studies on a discipline can be determined by analyzing the studies carried out in that discipline before. While determining the research trends, the trends of the data of years following the year taken as base are analyzed. The studies on determining the research trends may be used in projecting the future events, as well as determining the conditions of discipline in past. In other words, by using the date obtained for the period being discussed, it is aimed to estimate the conditions of the discipline, which is being analyzed, in the past or to project the future status of it (Ozan \& Köse, 2013). In parallel with the reflections of globalization and social-political trends, the philosophies taken as base in education in Turkey have been changed, consequently the curricula of basic education, secondary education, and teacher education programs have been modified in this parallel. This process affected the student profile, quality of pre-service and in-service education, necessities of teachers, and subjects of the studies carried out in Curriculum and Instruction discipline.

It can be seen that the similar studies (Semerci and Meral, 2007; Özdemir and Ar1, 2008; Saracaloğlu and Dursun, 2010; B1kmaz et al., 2013; Gömleksiz and Bozpolat, 2013; Kaya, 2014; Ozan and Köse, 2014; Kurt and Erdoğan, 2015; Kozikoğlu and Senemoğlu, 2015) have been carried out on examining the postgraduate and doctorate dissertations in Curriculum and Instruction discipline. These studies incorporate different variables in order to measure the trends of postgraduate researches. Some of the researches analyzed the postgraduate theses based on the researcher and content, whereas some others examined the theses from a wide perspective from the gender of researcher to the year of thesis' approval. But, in the critics made to Curriculum and Instruction discipline in Turkey, the lack of a studies analyzing the acceptance of students to postgraduate education, entrance exams, content, quality of education, and assessment dimensions becomes more prominent. Accordingly, the objective of present study is to analyze the postgraduate and doctorate dissertations written in Curriculum and Instruction disciplines between 1974 and 2017 in Turkey from various aspects such as university, year, research subject, terms of acceptance and graduation, courses given, and number of academic personnel. The present study is believed to contribute significantly to informing the researchers and educators about the most prominent research subjects and most frequently offered courses in field of Curriculum and Instruction, and determining the method and scope of their own studies. For this reason, the present study is believed to be important since it reveals the actual trends, subjects, and changes in postgraduate and doctorate dissertations in Curriculum and Instruction disciplines, guides the researches, enables the assessments and evaluations on previous studies, and determines the direction for future studies in order to meet the deficiencies and necessities.

In parallel with this objective, the answers to following questions were sought:

Branches of Curriculum and Instruction Department;

- What are the actual conditions of academic personnel?

- What are the terms of acceptance?

- Which courses are lectured?

- What are the terms of graduation?

- How do the published postgraduate theses in terms of subject and year of publication?.

\section{Method}

This study is a descriptive study examining which results the Curriculum and Instruction discipline and the postgraduate and doctorate thesis prepared in Curriculum and Instruction discipline in Turkey yielded in parallel with the research questions. The "document analysis" method, in which the written documents including information about the cases that have been examined are analyzed qualitatively, was employed in the present study (Yıldırım and Şimşek, 2011). In this parallel, the steps followed are to determine the documents, to check the originality of documents, to analyze the data, and to report the results, respectively (İşcan and B1kmaz, 2012). The information about the branches of Curriculum and Instruction was obtained from the official webpages of relevant universities, whereas the theses were obtained from the database of National Thesis Center of YÖK.

\section{Data Collection}

In the present study, totally 28 universities having both postgraduate and doctorate programs in Curriculum and Instruction discipline, and totally 1599 theses written in these universities between 1974 and 2017 were analyzed. Given all the postgraduate programs in Curriculum and Instruction discipline in Turkey, it can be seen 
that the validity level of study is high. Besides that, YÖK thesis center and actual postgraduate ordinances of universities were taken into consideration in collecting the data.

Since the study was carried out by a group, each of the researchers analyzed certain universities. Then the theses that have been examined were gathered, then ordered based on their subjects, and then their themes were determined. The group discussions were made on the determined themes, and the final form was determined based on consensus. For this reason, ensuring the consistency of determined themes was considered important. The instruction of data collection was prepared in accordance with the objectives of study. This analysis instruction is presented below.

Curriculum and Instruction Branches;

- Academic personnel: numbers and titles of academicians working in branches of Curriculum and Instruction (Prof. Dr, Assoc. Prof. Dr, Assist. Prof. Dr., Research Assistant, and Instructor) were examined.

- Terms of acceptance: The requirements of candidates' acceptance to postgraduate or doctorate programs were examined as ALES score and type of this score, foreign language score, and department of graduation.

- Lectures: The compulsory and optional lectures throughout the postgraduate education. These lectures were categorized based on the subjects by the researcher.

- Terms of graduation: The minimum number of lectures and the general point average required for graduation forms the postgraduate Curriculum and Instruction programs of universities were examined.

Postgraduate theses written in Curriculum and Instruction branches were examined according to the criteria specified below:

- Postgraduate and doctorate level,

- Year of acceptance,

- Universities, in which they have been published

\section{Data Analysis}

The data collected were transferred to Excel and SPSS 22 package programs and then the frequency (f) and percentage (\%) values were calculated for the number of academic personnel, terms of acceptance, lectures given, terms of graduation, and theses based on the subjects and universities.

\section{Results and Discussion}

In this section, the results obtained are presented in parallel with the objectives of present study.

\section{Total Number of Academic Personnel in Universities}

In 28 universities involved in present analysis in Turkey, totally 283 academic personnel work in Curriculum and Instruction branches. By examining the distribution of academic personnel among the universities, it was found that Gazi University has the highest number of academician (28 academicians) in Curriculum and Instruction branches among the universities in Turkey. This constitutes $9.9 \%$ of all the academicians working in branches of Curriculum and Instruction. Following the Gazi University, the other universities having highest number of academicians are Middle East Technical University (20), Hacettepe University (19), Yıldı Technical University (16) and Muğla Sttkı Koçman University (15). These universities have 34.7\% of all the academic personnel. On the other hand, the universities employing lowest numbers of academic personnel were Dokuz Eylül University (2), Düzce University (2), Bülent Ecevit University (3) and Afyon Kocatepe University (4). These universities constitute $3.9 \%$ of academic personnel in total. The frequency and percentage distribution of the total academic staff at universities are shown in Table 1.

Table 1. Frequency and percentage distribution of total academic staff in universities

\begin{tabular}{lll} 
Universities & f & \% \\
\hline Dokuz Eylül University & 2 & 0,7 \\
Düzce University & 2 & 0,7 \\
Bülent Ecevit University & 3 & 1,1 \\
Afyon Kocatepe University & 4 & 1,4 \\
\hline
\end{tabular}




\begin{tabular}{|c|c|c|}
\hline Akdeniz University & 6 & 2,1 \\
\hline Gaziosmanpaşa University & 6 & 2,1 \\
\hline Abant İzzet Baysal University & 7 & 2,5 \\
\hline Cumhuriyet University & 7 & 2,5 \\
\hline Firat University & 7 & 2,5 \\
\hline Anadolu University & 8 & 2,8 \\
\hline Çanakkale Onsekiz Mart University & 8 & 2,8 \\
\hline Ege University & 8 & 2,8 \\
\hline Mersin University & 8 & 2,8 \\
\hline Osmangazi University & 8 & 2,8 \\
\hline Atatürk University & 9 & 3,2 \\
\hline Dicle University & 9 & 3,2 \\
\hline Gaziantep University & 9 & 3,2 \\
\hline Balıkesir University & 10 & 3,5 \\
\hline İnönü University & 10 & 3,5 \\
\hline Yüzüncü Yıl University & 10 & 3,5 \\
\hline Çukurova University & 11 & 3,9 \\
\hline Ankara University & 14 & 4,9 \\
\hline Muğla Sitkı Koçman University & 15 & 5,3 \\
\hline Yıldız Teknik University & 16 & 5,7 \\
\hline Adana Menderes University & 19 & 6,7 \\
\hline Hacettepe University & 19 & 6,7 \\
\hline Orta Doğu Teknik University & 20 & 7,1 \\
\hline Gazi University & 28 & 9,9 \\
\hline Total & 283 & 100 \\
\hline
\end{tabular}

\section{Distribution of Academic Personnel in Universities by their Titles}

From the aspect of titles, most of the academic personnel (33.2\%) have the title of research assistant (94 academicians). Following the research assistants, the second highest portion belongs to assistant professors, whereas minimum (3.2\%) portion belongs to the instructors (9). The universities employing highest number of professors in Curriculum and Instruction branches are in Gazi University (8), Middle East Technical University (4), Muğla Sttkı Koçman University (3), and Anadolu University (3), respectively. The professors in Turkey constitute $14.5 \%$ of all the academic personnel. The universities employing highest number of associate professors working in Curriculum and Instruction branches are Y1ldiz Technical University (5), Mersin University (4), Gazi University (5), and İnönü University (4). The associate professors in Turkey constitute $19.4 \%$ of all the academic personnel. The universities having highest number of assistant professors in Turkey are Gazi University (8), Çanakkale University (6), Cumhuriyet University (5), and İnönü University (5). The assistant professors in Turkey constitute $29.7 \%$ of all the academic personnel. The universities employing highest number of research assistants working in branches of Curriculum and Instruction are Middle East 
Technical University (13), Ankara University (9), Hacettepe University (9), and Muğla Sitk1 Koçman University (6). The research assistants in Turkey constitute $33.2 \%$ of all the academic personnel. The universities employing the highest number of instructors working in branches of Curriculum and Instruction are Gazi University (3), Balıkesir University (2), Çukurova University (1), Yıldız Technical University (1), Van Yüzüncü Y1l University (1), Hacettepe University (1), and Adnan Menderes University (1). In other universities, no one having the "instructor" title works. Instructors constitute $3.2 \%$ of all the academic personnel. The distribution of the total academic staff at the universities by title is shown in Table 2 .

Table 2. Frequency and percentage distribution of total academic staff by title

\begin{tabular}{lcc}
\hline Title & f & \% \\
\hline Instructor & 9 & 3,2 \\
Prof. Dr. & 41 & 14,5 \\
Assoc. Prof. Dr. & 55 & 19,4 \\
Asst. Prof. Dr. & 84 & 29,7 \\
Res. Asst. & 94 & 33,2 \\
\hline Total & $\mathbf{2 8 3}$ & $\mathbf{1 0 0}$ \\
\hline
\end{tabular}

\section{Distribution of ALES Scores in Postgraduate Application to Curriculum and Instruction Branches of Universities}

According to the analysis results, $78.6 \%$ of the countries specified the lower limit of ALES score to be 55 for applying to postgraduate programs, $17.9 \%$ specified ALES score to be 60, and 3.6\% determined the lower limit to be 65 . For applying to the doctorate programs, the lower limit of ALES score was set to be 55 by $57.1 \%$ of universities, 60 by $21.4 \%, 65$ by $3.6 \%$, and 70 by $7.1 \%$. Since no student is accepted to doctorate programs in $10.7 \%$ of universities, no lower limit was determined for ALES score. In total, it was observed that the most frequently specified lower limit of ALES score for the postgraduate and doctorate programs in branches of Curriculum and Instruction is 55 points. The frequency and percentage distribution of the ALES scores requested by the universities in the graduate applications of the Curriculum and Instruction Department are shown in Table 3.

Table 3. Frequency and percentage distribution of the ales scores that the universities wanted for graduate applications in the department of curriculum and instruction

\begin{tabular}{|c|c|c|c|c|c|c|c|c|c|}
\hline \multirow{2}{*}{ ALESScore } & \multicolumn{3}{|c|}{ Master Pror Programs } & \multicolumn{3}{|c|}{$\begin{array}{l}\text { Doctorate Programs } \\
\text { Doctorate Progranms }\end{array}$} & \multicolumn{3}{|c|}{ Total Total } \\
\hline & $\mathbf{f}$ & $\mathbf{f}$ & $\% \quad \%$ & f & $\mathbf{f}$ & $\% \%$ & $f$ & $\mathbf{f}$ & $\% \%$ \\
\hline 55 Verbal & 22 & 2 & $78,6 \% 97,1 \%$ & 16 & 2 & $57,1 \%, 1 \%$ & 38 & 4 & $67,9 \%, 1 \%$ \\
\hline 60 & 5 & & $17,9 \%$ & 6 & & $21,4 \%$ & 11 & & $19,6 \%$ \\
\hline 65 & 1 & & $3,6 \%$ & 1 & & $3,6 \%$ & 2 & & $3,6 \%$ \\
\hline 70 & 0 & & $0,0 \%$ & 2 & & $7,1 \%$ & 2 & & $3,6 \%$ \\
\hline Unknown & 0 & & $0,0 \%$ & 3 & & $10,7 \%$ & 3 & & $5,4 \%$ \\
\hline Total & 28 & & $100,0 \%$ & 28 & & $100,0 \%$ & 56 & & $100,0 \%$ \\
\hline
\end{tabular}

Distribution of ALES Score Type in Application to Postgraduate Programs in Curriculum and Instruction Branches of Universities 


\begin{tabular}{lcccccc} 
Equal Weight & 18 & $64,3 \%$ & 17 & $60,7 \%$ & 35 & $62,5 \%$ \\
Verbal/Equal Weight & 4 & $14,3 \%$ & 3 & $10,7 \%$ & 7 & $12,5 \%$ \\
$\begin{array}{l}\text { Numerical/Verbal/Equal } \\
\text { Weight }\end{array}$ & 3 & $10,7 \%$ & 2 & $7,1 \%$ & 5 & $8,9 \%$ \\
Graduated type of score & 1 & $3,6 \%$ & 1 & $3,6 \%$ & 2 & $3,6 \%$ \\
Unknown & 0 & $0 \%$ & 3 & $10,7 \%$ & 3 & $5,4 \%$ \\
\hline Total & $\mathbf{2 8}$ & $\mathbf{1 0 0 , 0 \%}$ & $\mathbf{2 8}$ & $\mathbf{1 0 0 , 0 \%}$ & $\mathbf{5 6}$ & $\mathbf{1 0 0 , 0 \%}$ \\
\hline
\end{tabular}

It was determined that, in application to postgraduate education programs, $67.1 \%$ of universities require verbal/linguistic ALES score, 64.3\% require equal-weighted ALES score, 14.3\% verbal/equal-weighted ALES score, $10.7 \%$ mathematics/verbal/equal-weighted ALES score, and 3.6\% the score type of graduation. In application to the doctorate programs, $7.1 \%$ of the universities require verbal ALES score, $60.7 \%$ equalweighted ALES score, 10.7\% verbal/equal-weighted ALES score, 7.1\% mathematics/verbal/equal-weighted ALES score, and $3.6 \%$ the score type of graduation. Since no student is accepted to doctorate programs in $10.7 \%$ of universities, no lower limit was determined for ALES score. In total, the most frequently requested type of ALES score for application to the Curriculum and Instruction branches in universities is the equalweighted ALES score. The frequency and percentage distribution of the ALES score type requested by the universities in the Curriculum and Instruction Department graduate applications are shown in Table 4.

Table 4. Frequency and percentage distribution of ales score type required for graduate admission of universities in the department of curriculum and instruction

\section{Distribution of Foreign Language Score Required for Applying to Postgraduate Education in Curriculum and Instruction Branches in Universities}

In application to postgraduate education programs of universities, the minimum foreign language score requested is 40 points in $17.9 \%$ of universities, 50 in 10.7\%, 55 in 3.6\%, 65 in $3.6 \%$, and the score determined by the university senate in $3.6 \%$. However, $21.4 \%$ of universities require no foreign language score, whereas the minimum foreign language score is not known for $35.7 \%$. In application to the doctorate programs, the minimum foreign language score is 40 points in $3.6 \%$ of universities, 55 points in $53.6 \%$, 60 points in $10.7 \%$, and 65 points in $7.1 \% .25 \%$ of the universities have no foreign language score requirement. Here, it can be concluded that the lower limit for foreign language score required for applying to postgraduate programs in branches of Curriculum and Instruction is not known for most of universities. However, most frequently requested base score of foreign language exam for application to doctorate programs is 55 points. The frequency and percentage distribution of the ALES scores requested by the universities in the graduate applications of the Curriculum and Instruction Department are shown in Table 5.

Table 5. Frequency and percentage distribution of the desired language scores of the universities

\begin{tabular}{lcccccc}
\hline \multirow{2}{*}{ Language Score } & \multicolumn{2}{c}{ Master Programs } & \multicolumn{2}{c}{ Doctorate Programs } & \multicolumn{2}{c}{ Total } \\
\hline 40 & $\mathbf{f}$ & $\mathbf{\%}$ & $\mathbf{f}$ & $\mathbf{\%}$ & $\mathbf{f}$ & $\mathbf{\%}$ \\
50 & 5 & $17,9 \%$ & 1 & $3,6 \%$ & 6 & $10,7 \%$ \\
55 & 3 & $10,7 \%$ & 0 & $0 \%$ & 3 & $5,4 \%$ \\
60 & 1 & $3,6 \%$ & 15 & $53,6 \%$ & 16 & $28,6 \%$ \\
65 & 1 & $3,6 \%$ & 3 & $10,7 \%$ & 4 & $7,1 \%$ \\
Senate Decisions & 1 & $3,6 \%$ & 2 & $7,1 \%$ & 3 & $5,4 \%$ \\
Not required & 1 & $3,6 \%$ & 0 & $0 \%$ & 1 & $1,8 \%$ \\
Unknown & 6 & $21,4 \%$ & 0 & $0 \%$ & 6 & $10,7 \%$ \\
\hline Total & 10 & $35,7 \%$ & 7 & $25,0 \%$ & 17 & 30,4 \\
\hline
\end{tabular}




\section{Distribution of Graduation Faculty Specified in Application to Postgraduate Education Programs in Curriculum and Instruction Branches of Universities}

In application for postgraduate education program in branches of Curriculum and Instruction, $46.4 \%$ of universities accept those graduated from faculty of education, $17.9 \%$ accept graduates of faculty of education or those having pedagogical formation, $7.1 \%$ graduates of any 4-year undergraduate program, 3.6\% graduates of faculty of science and letters, $3.6 \%$ graduates of faculty of education or faculty of technical education, and $3.6 \%$ graduates of faculty of education or police academy or military academy. However, $14.3 \%$ of universities specified no condition, and 3.6\% of universities accept no student. For the application to postgraduate program, Atatürk University specified the requirement of graduation from the departments of Preschool Teaching, Education of Mentally Handicapped Individuals, Psychological Counseling and Guidance, Computer and Instructional Technology Teaching, and English Teaching (undergraduate). Çukurova University specified the graduation from one of the departments of Curriculum and Instruction, Primary School Teaching, Computer and Instructional Technologies Teaching, Science Teaching, Preschool Teaching, Turkish Teaching, Social Sciences Teaching, Primary School Math Teaching, or one of the branches of Department of Philosophy. The distribution of the graduated faculties specified by the universities in the graduate applications of the Curriculum and Instruction Department is shown in Table 6.

Table 6.Frequency and percentage distribution of the graduated faculties stated by the universities in the graduate applications of the department of curriculum and instruction

\begin{tabular}{lcc} 
Graduated Faculty & Master Programs & \% \\
\hline FoE/Fak of Art and Science & $\mathbf{f}$ & $3,60 \%$ \\
FoE /Technical FoE & 1 & $3,60 \%$ \\
FoE/PoliceAcad./Military Collage & 1 & $3,60 \%$ \\
No student intake & 1 & $3,60 \%$ \\
4 Years Department & 1 & $7,10 \%$ \\
Does not want any requirement & 2 & $14,30 \%$ \\
FoE/Initial Teacher Training & 4 & $17,90 \%$ \\
Faculty of Education(FoE) & 5 & $46,40 \%$ \\
\hline Total & 13 & $\mathbf{1 0 0 , 0 \%}$ \\
\hline
\end{tabular}

\section{Distribution of Faculties Specified by Universities for Application to Doctorate in Curriculum and Instruction Department}

For application to doctorate in branches of Curriculum and Instruction, 39.3\% of universities declared to accept Curriculum and Instruction postgraduates, $7.1 \%$ postgraduates from faculty of education, $3.6 \%$ education faculty graduates, $3.6 \%$ those graduated from the faculty of education or having pedagogical formation, 3.6\% postgraduates from educational sciences or Curriculum and Instruction, and 3.6\% graduates form any undergraduate program. But, $14.3 \%$ of universities specified no condition, and $21.4 \%$ accepts no student. For application to doctorate, Çukurova University requires having postgraduate degree from Curriculum and Instruction, Primary School Teaching, Preschool Teaching, Computer and Instructional Technologies Teaching, Educational Sciences, and branches of Department of Primary School Teaching or having undergraduate degree in Faculty of Education. The distribution of the graduated faculties specified by the universities in the $\mathrm{PhD}$ applications for Curriculum and Instruction is shown in Table 7.

Table 7. Frequency and percentage distribution of graduated faculties stated by universities in phd applications in curriculum and instruction department 


\begin{tabular}{llc} 
& f & $\mathbf{\%}$ \\
\hline FoE/Initial Teacher Training & 1 & $3,60 \%$ \\
Faculty of Education(FoE) & 1 & $3,60 \%$ \\
$\begin{array}{l}\text { Educational Science Master Degree or } \\
\text { Curr. And Ins. Master Degree }\end{array}$ & 1 & $3,60 \%$ \\
4 Years Department & 1 & $3,60 \%$ \\
Educational Science Master Degree & 2 & $7,10 \%$ \\
Does not want any requirement & 4 & $14,30 \%$ \\
No student intake & 6 & $21,40 \%$ \\
Curr. And Ins. Master Degree & 11 & $39,30 \%$ \\
\hline Total & $\mathbf{2 8}$ & $\mathbf{1 0 0 , 0 \%}$ \\
\hline
\end{tabular}

\section{Distribution of Number of Lectures in Curriculum and Instruction Departments of Universities}

In all of Curriculum and Instruction departments in Turkey, there are totally 729 postgraduate lectures. The highest number of lectures belongs to Middle East Technical University (108), Düzce University (57), Çanakkale University (56), Frrat University (50) and Adnan Menderes University (50), respectively. On the other hand, the lowest number of lectures belongs to Atatürk University (5), Gaziantep University (7), Ankara University (11), Hacettepe University (12) and Gaziosmanpaşa University (13), respectively.

\section{Distribution of Postgraduate and Doctorate Lecture Themes}

In the present study, the postgraduate lectures were gathered under 14 main themes named Scientific Research (8.5\%), Education of Thinking (4\%), Educational Researches (1\%), Basics of Educational Curricula $(12.1 \%)$, Problems in Education (5.8\%), Types of Education (5.9\%), Management in Education $(2.1 \%)$, New Approaches in Education (3.2\%), Statistics (5.5\%), Basics of Teaching and Learning (17.3\%), Educating the Teachers (3.6\%), Measurement and Assessment (5.3\%), Curriculum (28.8\%) and Project Development (7\%). While creating themes, each relevant section was examined and coded in accordance with research questions. While determining the themes, the data entered were first examined and put together. It was tried to find common aspects between the data. Themes were determined by bringing together and numbered data that are related to each other.

Given the lecture themes in postgraduate and doctorate programs, it was determined that the highest number of lectures is in main themes of curriculum (210), basics of teaching and learning (126), and basics of curriculum (88). The themes of education of thinking (3), project development (5) and educational researches have the minimum number of lectures in their curricula. Master and Doctorate course themes are shown in Table 8.

Table 8. Frequency and percentage distribution of master and doctorate course themes

\begin{tabular}{lcc} 
Course Themes & f & \% \\
\hline Education of Thinking & 3 & 0,4 \\
Project Development & 5 & 0,7 \\
Educational Researches & 7 & 1 \\
Management in Education & 15 & 2,1 \\
New Approaches in Education & 23 & 3,2 \\
Educating the Teachers & 26 & 3,6 \\
\hline
\end{tabular}




\begin{tabular}{lcc}
\hline Measurement and Assessment & 39 & 5,3 \\
Statistics & 40 & 5,5 \\
Problems in Education & 42 & 5,8 \\
Types of Education & 43 & 5,9 \\
Scientific Research & 62 & 8,5 \\
Basics of Educational Curricula & 88 & 12,1 \\
Basics of Teaching and Learning & 126 & 17,3 \\
Curriculum & 210 & 28,8 \\
\hline Total & $\mathbf{7 2 9}$ & $\mathbf{1 0 0 , 0}$ \\
\hline
\end{tabular}

\section{The Distribution of Most Frequent Lectures in Lecture Theme of Curriculum and Basics of Teaching and Learning}

The theme of Curriculum was divided into three different subthemes named assessment (20\%), development $(43.3 \%)$ and others (36.7\%). The subtheme "others" is given this name because it covers many lectures. The theme of Basics of Teaching and Learning is divided into six subthemes named approach (31.7\%), others $(25.4 \%)$, design $(14.3 \%)$, fundamentals of teaching and learning $(13.5 \%)$, method and technique $(11.9 \%)$, and informatics (3.2\%). Since there are many different lectures under subtheme of "others" and they cannot be separately given themes, they are gathered under the single theme of "others". The distribution of the most taught courses in the program course theme is given in Table 9.

Table 9. Frequency and percentage distribution of the most taught courses in the program course theme

\begin{tabular}{lll} 
Course Theme & f & \% \\
\hline Evaluation & 42 & 20 \\
Others & 77 & 36,7 \\
Development & 91 & 43,3 \\
\hline Total & $\mathbf{2 1 0}$ & $\mathbf{1 0 0 , 0}$ \\
\hline
\end{tabular}

\section{Distribution of the Number of Lectures Required for Graduating from Postgraduate and Doctorate Programs in Curriculum and Instruction Departments of Universities}

For graduation from postgraduate programs, the number of lectures to pass was specified to be minimum 7 by $82.1 \%$ of universities, 8 by $10.7 \%$, and minimum 9 by $7.1 \%$. For the graduation from doctorate programs, the number of lectures to pass was specified to be minimum 7 by $64.3 \%$ of universities, minimum 8 by $14.3 \%$, minimum 9 by $7.1 \%$, and minimum 10 by $10.7 \% .3 .6 \%$ of the universities do not specify the number of lectures to pass, because one of universities accepts no new student in doctorate programs. It can be seen that most of the universities require the students to pass minimum 7 lectures in order to graduate from postgraduate or doctorate programs such as Akdeniz University, Afyon Kocatepe University and Çukurova University. Also some of the universities require the students to pass minimum 8 lectures in order to graduate from postgraduate or doctorate programs such as Abant İzzet Baysal University and Adnan Menderes University. Frequency and percentage distribution regarding the number of courses to be taken in order to graduate from the graduate and doctorate programs of the Curriculum and Instruction Department of Universities are shown in Table 10. 
Table 10. Frequency and percentage distribution of the number of courses to be taken to be graduated from the graduate and doctorate programs of the university

\begin{tabular}{lcccccc}
\hline $\begin{array}{l}\text { Number of } \\
\text { Courses }\end{array}$ & \multicolumn{2}{c}{ Master Programs } & \multicolumn{2}{c}{ PhD programs } & \multicolumn{2}{c}{ Total } \\
\hline 7 & f & $\mathbf{\%}$ & f & $\mathbf{\%}$ & f & \% \\
\hline 8 & 23 & $82,1 \%$ & 18 & $64,3 \%$ & 41 & $73,2 \%$ \\
9 & 3 & $10,7 \%$ & 4 & $14,3 \%$ & 7 & $12,5 \%$ \\
10 & 2 & $7,1 \%$ & 2 & $7,1 \%$ & 4 & $7,1 \%$ \\
Unknown & 0 & $0 \%$ & 3 & $10,7 \%$ & 3 & $5,4 \%$ \\
\hline Total & 0 & $0 \%$ & 1 & $3,6 \%$ & 1 & $1,8 \%$ \\
\hline
\end{tabular}

\section{Distribution of the Grade-Point Averages Required by the Universities for Graduating from Postgraduate and Doctorate Programs in Curriculum and Instruction Departments}

The grade-point average required for graduating from the postgraduate program in Curriculum and Instruction department is set to be minimum $1.50 / 4.00$ by $10.7 \%$ of universities, $2.00 / 4.00$ by $46.4 \%, 2.50 / 4.00$ by $28.46 \%, 2.75 / 4.00$ by $3.6 \%$, and $3.00 / 4.00$ by $10.7 \%$. The grade-point average required for graduating from the doctorate program in Curriculum and Instruction department is set to be minimum 2.00/4.00 by $7.1 \%$ of universities, $2.50 / 4.00$ by $46.4 \%, 3.00 / 4.00$ by $39.3 \%, 3.25 / 4.00$ by $3.6 \%$, and $3.50 / 4.00$ by $3.6 \%$. It can be seen that most of universities require minimum 2.00/4.00 GPA for graduating from postgraduate programs and minimum 2.50/4.00 for graduating from doctorate programs. The frequency and percentage distribution regarding the graduation grade average required to graduate from the universities' graduate programs in the Curriculum and Instruction Department are shown in Table 11.

Table 11. Frequency and percentage distribution of the average grade that the universities have set for graduating from the graduate and $\mathrm{PhD}$ programs of curriculum and instruction

\begin{tabular}{lcccccc}
\hline \multirow{2}{*}{$\begin{array}{l}\text { Grade-Point } \\
\text { Averages }\end{array}$} & \multicolumn{2}{c}{ Master Programs } & \multicolumn{2}{c}{ PhD programs } & \multicolumn{2}{c}{ Total } \\
\hline $1.50 / 4.00$ & f & $\mathbf{\%}$ & f & $\mathbf{\%}$ & f & \% \\
$2.00 / 4.00$ & 3 & $10,7 \%$ & 0 & $0 \%$ & 3 & $5,4 \%$ \\
$2.50 / 4.00$ & 13 & $46,4 \%$ & 2 & $7,1 \%$ & 15 & $26,8 \%$ \\
$2.75 / 4.00$ & 8 & $28,6 \%$ & 13 & $46,4 \%$ & 21 & $37,5 \%$ \\
$3.00 / 4.00$ & 1 & $3,6 \%$ & 0 & $0 \%$ & 1 & $1,8 \%$ \\
$3.25 / 4.00$ & 3 & $10,7 \%$ & 11 & $39,3 \%$ & 14 & $25,0 \%$ \\
$3.50 / 4.00$ & 0 & $0 \%$ & 1 & $3,6 \%$ & 1 & $1,8 \%$ \\
\hline Total & 0 & $0 \%$ & 1 & $3,6 \%$ & 1 & $1,8 \%$ \\
\hline
\end{tabular}

\section{Distribution of Theses Written between 1974 and 2017 in Department of Curriculum and Instruction in Turkey}

Among 1599 theses involved in this analysis, 1162 were postgraduate theses $(72.7 \%)$, whereas 437 were doctorate dissertation (27.3\%). This indicates that the number of persons writing postgraduate thesis in branches of Curriculum and Instruction is higher than those writing doctorate thesis in branches of Curriculum and 
Instruction. Curriculum and Instruction Department of the thesis written between 1974 and 2017, the frequency and percentage distributions in Turkey is shown in Table 12.

Table 12. Curriculum and instruction department of the year in 1974 and 2017 between the distribution of the thesis in turkey

\begin{tabular}{lcc}
\hline Degree & f & \% \\
\hline Master degree & 1162 & 72,7 \\
PhD degree & 437 & 27,3 \\
\hline Total & $\mathbf{1 5 9 9}$ & $\mathbf{1 0 0 , 0}$ \\
\hline
\end{tabular}

\section{Distribution of Postgraduate and Doctorate Dissertation Written between 1974 and 2017 in Department of Curriculum and Instruction in Turkey between the Universities}

According to the results obtained from 1162 postgraduate and 437 doctorate dissertation written in 28 universities, the highest number of postgraduate theses belongs to Gazi University (98, 8.4\%), Hacettepe University $(81,7 \%)$ and Gaziantep University $(75,6.2)$, respectively. The lowest number of postgraduate theses belongs to Atatürk University (16, 1.4\%), Düzce University $(12,1 \%)$ and Balıkesir University $(9,0.8 \%)$, respectively.

Given the doctorate dissertations, the highest number of theses belongs to Hacettepe University $(61,14 \%)$, Middle East Technical University (47, 10.8\%) and Ankara University (32, 7.3\%), respectively. It was determined that no doctorate thesis has been written in Akdeniz University, Bülent Ecevit University, Cumhuriyet University, Düzce University, and Muğla Sttkı Koçman University. In terms of the total of postgraduate and doctorate dissertations, first three ranks belong to Hacettepe University with 142 theses (10.5\%), Gazi University with 122 theses (6.95\%) and Middle East Technical University with 111 theses (8.15\%). Distribution of Postgraduate and Doctorate Dissertation Written between 1974 and 2017 in Department of Curriculum and Instruction in Turkey between the Universities is shown in Table 13.

Table 13. Distribution of postgraduate and doctorate dissertation written between 1974 and 2017 in department of curriculum and instruction in turkey between the universities

\begin{tabular}{lcccccc}
\multicolumn{1}{c}{ Universities } & \multicolumn{7}{c}{ Master Programs } & PhD programs & Total & \\
& f & \% & f & \% & f & \% \\
\hline Abant İzzet Baysal University & 60 & 5,2 & 31 & 7,1 & 91 & 6,2 \\
Adana Menderes University & 43 & 3,7 & 15 & 3,4 & 58 & 3,6 \\
Afyon Kocatepe University & 39 & 3,4 & 1 &, 2 & 40 & 1,8 \\
Akdeniz University & 39 & 3,4 & 0 & 0 & 39 & 1,7 \\
Anadolu University & 21 & 1,8 & 22 & 5,0 & 43 & 3,4 \\
Ankara University & 69 & 5,9 & 32 & 7,3 & 101 & 6,6 \\
Atatürk University & 16 & 1,4 & 7 & 1,6 & 23 & 1,5 \\
Balıkesir University & 9 &, 8 & 8 & 1,8 & 17 & 1,3 \\
Bülent Ecevit University & 23 & 2,0 & 0 & 0 & 23 & 1,0 \\
Cumhuriyet University & 18 & 1,5 & 0 & 0 & 18 & 0,8 \\
Çanakkale Onsekiz Mart University & 37 & 3,2 & 14 & 3,2 & 51 & 3,2 \\
Çukurova University & 65 & 5,6 & 29 & 6,6 & 94 & 6,1
\end{tabular}




\begin{tabular}{lcccccc} 
Dicle University & 29 & 2,5 & 9 & 2,1 & 38 & 2,3 \\
Dokuz Eylül University & 44 & 3,8 & 16 & 3,7 & 60 & 3,8 \\
Düzce University & 12 & 1,0 & 0 & 0 & 12 & 0,5 \\
Ege University & 25 & 2,2 & 5 & 1,1 & 30 & 1,7 \\
Fırat University & 44 & 3,8 & 27 & 6,2 & 71 & 5,0 \\
Gazi University & 98 & 8,4 & 24 & 5,5 & 122 & 7,0 \\
Gaziantep University & 75 & 6,5 & 25 & 5,7 & 100 & 6,1 \\
Gaziosmanpaşa University & 38 & 3,3 & 1 &, 2 & 39 & 1,8 \\
Hacettepe University & 81 & 7,0 & 61 & 14,0 & 142 & 10,5 \\
İnönü University & 38 & 3,3 & 24 & 5,5 & 62 & 4,4 \\
Mersin University & 21 & 1,8 & 10 & 2,3 & 31 & 2,1 \\
Muğla Sitkı Koçman University & 38 & 3,3 & 0 & 0 & 38 & 1,7 \\
Orta Doğu Teknik University & 64 & 5,5 & 47 & 10,8 & 111 & 8,2 \\
Yıldız Teknik University & 72 & 6,2 & 26 & 5,9 & 98 & 6,1 \\
Yüzüncü Yıl University & 44 & 3,8 & 3 &, 7 & 47 & 2,3 \\
\hline Total & $\mathbf{1 1 6 2}$ & $\mathbf{1 0 0 , 0}$ & $\mathbf{4 3 7}$ & $\mathbf{1 0 0 , 0}$ & $\mathbf{1 5 9 9}$ & $\mathbf{1 0 0 , 0}$ \\
\hline
\end{tabular}

Distribution of Postgraduate and Doctorate Dissertations Written between 1974 and 2017 in Department of Curriculum and Instruction in Turkey between the Years

Examining the years, when the postgraduate theses were accepted, it was accepted that the highest number of postgraduate theses was accepted in 2010 with 105 theses (9\%), followed by 2014 with 102 theses $(8.8 \%), 2015$ with 100 theses (8.6\%), 2013 with 99 theses (8.5\%), 2012 with 95 theses (8.2\%), 2011 with 91 theses $(7.8 \%)$, and 2008 with 87 theses $(7.5 \%)$. Based on these results, it can be seen that the number of postgraduate theses increased since 2009. When the years, when doctorate dissertations were accepted, was examined, it was determined that, out of 437 theses that were analyzed, $52(11.9 \%)$ theses were accepted in 2016, $47(10.8 \%)$ theses in 2015, $46(10.5 \%)$ theses in 2013, $45(10.3 \%)$ theses in 2014, and $39(8.9 \%)$ theses in 2012. Based on these findings, it can be seen that a significant increase occurred in the number of postgraduate and doctorate dissertations in Curriculum and Instruction branches. Distribution of Postgraduate and Doctorate Dissertations Written between 1974 and 2017 in Department of Curriculum and Instruction in Turkey between the Years is shown in Table 14.

Table 14. Distribution of postgraduate and doctorate dissertations written between 1974 and 2017 in department of curriculum and instruction in turkey between the years

\begin{tabular}{lcccccc}
\multirow{2}{*}{ Years } & \multicolumn{2}{c}{ Master Programs } & \multicolumn{2}{c}{ PhD programs } & \multicolumn{2}{c}{ Total } \\
& f & \% & f & \% & f & \% \\
\hline Before 2000 & 30 & 2,6 & 19 & 4,3 & 49 & 3,5 \\
2000 & 7 &, 6 & 4 &, 9 & 11 & 0,8 \\
2001 & 19 & 1,6 & 7 & 1,6 & 26 & 1,6 \\
2002 & 18 & 1,5 & 6 & 1,4 & 24 & 1,5
\end{tabular}




\begin{tabular}{lllllll}
2003 & 30 & 2,6 & 7 & 1,6 & 37 & 2,1 \\
2004 & 43 & 3,7 & 10 & 2,3 & 53 & 3,0 \\
2005 & 28 & 2,4 & 10 & 2,3 & 38 & 2,4 \\
2006 & 61 & 5,2 & 22 & 5,0 & 83 & 5,1 \\
2007 & 64 & 5,5 & 27 & 6,2 & 91 & 5,9 \\
2008 & 87 & 7,5 & 25 & 5,7 & 112 & 6,6 \\
2009 & 99 & 8,5 & 21 & 4,8 & 120 & 6,7 \\
2010 & 105 & 9,0 & 23 & 5,3 & 128 & 7,2 \\
2011 & 91 & 7,8 & 24 & 5,5 & 115 & 6,7 \\
2012 & 95 & 8,2 & 39 & 8,9 & 134 & 8,6 \\
2013 & 99 & 8,5 & 46 & 10,5 & 145 & 9,5 \\
2014 & 102 & 8,8 & 45 & 10,3 & 147 & 9,6 \\
2015 & 100 & 8,6 & 47 & 10,8 & 147 & 9,7 \\
2016 & 80 & 6,9 & 52 & 11,9 & 132 & 9,4 \\
2017 & 4 &, 3 & 3 &, 7 & 7 & 0,5 \\
\hline Total & 1162 & $\mathbf{1 0 0 , 0}$ & $\mathbf{4 3 7}$ & $\mathbf{1 0 0 , 0}$ & $\mathbf{1 5 9 9}$ & $\mathbf{1 0 0 , 0}$ \\
\hline Distribution of Postgraduate and Doctorate & Dissertation & Written between \\
$\mathbf{2 0 1 7}$ in Department of Curriculum and Instruction in Turkey between the Themes
\end{tabular}

In 1599 postgraduate and doctorate dissertations prepared in 28 different universities, the researchers were observed to prefer different themes. The diversity of themes may be because the Curriculum and Instruction branches cover many disciplines and it is a comprehensive field. In determining these themes, the dependent variables taken as base in these studies were used. The subthemes were determined at first, and then the themes were determined. While creating themes, each relevant section was examined and coded in accordance with research questions. While determining the themes, the data entered were first examined and put together. It was tried to find common aspects between the data. Themes were determined by bringing together and numbered data that are related to each other. First five themes preferred most frequently in postgraduate and doctorate dissertations in Curriculum and Instruction branches between 1974 and 2017 were curriculum (Postgraduate - 25\%, Doctorate - 27,9\%), approach, strategy, and method (Postgraduate - 21.9\%, Doctorate $26.1 \%$ ), attitude and value education (Postgraduate $-14.8 \%$, Doctorate $-14.6 \%$ ), thinking education and learning strategies (Postgraduate - 11.6\%, Doctorate - 14.0\%), and informatics (Postgraduate - 7.2\%, Doctorate $-4.2 \%$ ). The least frequently preferred themes were special education (Postgraduate $-0.7 \%$, Doctorate $-0.2 \%$ ) and extracurricular activities (Postgraduate $-0.6 \%$, Doctorate $-0.0 \%$ ). It can be stated that the themes preferred in postgraduate and doctorate dissertations show parallelism. Distribution of Postgraduate and Doctorate Dissertation Written between 1974 and 2017 in Department of Curriculum and Instruction in Turkey between the Themes is shown in Table 15. 
Table 15. Distribution of postgraduate and doctorate dissertation written between 1974 and 2017 in department of curriculum and instruction in turkey between the themes

\begin{tabular}{lcccccc}
\hline & \multicolumn{2}{c}{ Master Programs } & \multicolumn{2}{c}{ PhD programs } & \multicolumn{2}{c}{ Total } \\
Themes & $\mathbf{f}$ & $\mathbf{\%}$ & $\mathbf{f}$ & $\mathbf{\%}$ & $\mathbf{f}$ & $\mathbf{\%}$ \\
\hline Informatics & 84 & 7,2 & 18 & 4,1 & 102 & 5,7 \\
Extracurricular Activities & 7 &, 6 & 0 & 0 & 7 & 0,3 \\
Thinking Education and Learning Strategies & 135 & 11,6 & 61 & 14,0 & 196 & 12,8 \\
Education Issues & 59 & 5,1 & 10 & 2,3 & 69 & 3,7 \\
Types of Education & 31 & 2,7 & 12 & 2,7 & 43 & 2,7 \\
Physical Environment & 19 & 1,6 & 4 &, 9 & 23 & 1,3 \\
Content & 15 & 1,3 & 5 & 1,1 & 20 & 1,2 \\
Teacher Competencies & 34 & 2,9 & 13 & 3,0 & 47 & 3,0 \\
Special education & 8 &, 7 & 1 &, 2 & 9 & 0,5 \\
Program & 290 & 25,0 & 122 & 27,9 & 412 & 26,5 \\
Program Basics & 37 & 3,2 & 11 & 2,5 & 48 & 2,9 \\
Classroom Management & 16 & 1,4 & 2 &, 5 & 18 & 1,0 \\
Attitude and Value Education & 172 & 14,8 & 64 & 14,6 & 236 & 14,7 \\
Approach, Strategy and Method & 255 & 21,9 & 114 & 26,1 & 369 & 24,0 \\
\hline Total & $\mathbf{1 1 6 2}$ & $\mathbf{1 0 0 , 0}$ & $\mathbf{4 3 7}$ & $\mathbf{1 0 0 , 0}$ & $\mathbf{1 5 9 9}$ & $\mathbf{1 0 0 , 0}$ \\
\hline
\end{tabular}

\section{Conclusion}

Among 28 universities (having both postgraduate and doctorate programs at the same time) involved in the present study, no postgraduate or doctorate thesis was published in branches of Curriculum and Instruction in Osmangazi University. 1163 postgraduate and 437 doctorate dissertations published in other 27 universities were analyzed based on universities, themes, and years. Then, the results obtained were discussed.

When all the theses were examined based on the universities, it was observed that most of the theses were prepared in Hacettepe, Gazi, METU and Ankara Universities (32.3\%). Among the universities, the highest number of theses was written in Gazi University in terms of postgraduate thesis and in Hacettepe University in terms of doctorate thesis. Similar to the present study, B1kmaz et al. (2013) reported in their study that the most of doctorate dissertations were written in Hacettepe, Middle East Technical, Dokuz Eylül and Ankara Universities. Since these universities are the leading ones in Curriculum and Instruction branches, it can be said that this is an expected result. The advantage of these universities in terms of the number of academicians may play role in this result.

It was determined that most of the analyzed doctorate dissertations written in branches of Curriculum and Instruction were written mainly in Hacettepe, Middle East Technical, Dokuz Eylül, and Ankara Universities.

When all the theses were examined in terms of year, when they were accepted, it can be seen that almost half (46.8\%) of the theses were written between 2012 and 2016. Especially the number of doctorate dissertations gradually increased in recent years. In literature, the similar results were obtained in studies carried out on doctorate dissertations by Bıkmaz et al. (2013) and Kozikoğlu \& Senemoğlu (2015). Moreover, given the statistics presented in Higher Education Information Management System webpage, a significant increase draws 
attention in the number of students that graduated from the Department of Educational Sciences. This situation may enable us to conduct various researches in terms of education. A serious number of teams can be created to prevent common problems in education. It can help to raise the education level of the our country.

When all the theses were analyzed from the aspect of themes, it was found that $78 \%$ of the theses were written on "curriculum (curriculum development, curriculum assessment, etc.)", "approach, strategy, and method", "attitude and value education" and "thinking education and learning strategies". On the other hand, the themes "Informatics", "Problems in Education", "Basics of Curriculum", "Competencies of Teachers", "Types of Education", Physical Environment", "Content", "Class Management", "Special Education", and "Extracurricular Activities" are less frequently studied. Moreover, it was also determined that the study subjects have diversified in recent years.

The theme "curricula", which was the most frequently researched, was most frequently studies in year 2010 in terms of postgraduate theses and 2015 in terms of doctorate dissertations, whereas this theme was most frequently studies in Ankara University in terms of postgraduate theses and Hacettepe in terms of doctorate dissertations. Then, the theme "approach, strategy, and method" was most frequently studied in 2014 and in Hacettepe University as postgraduate and doctorate dissertations. The theme "attitude and value education was most frequently studied as postgraduate thesis in 2015 and as doctorate thesis in 2016 and in Middle East Technical University as postgraduate and doctorate dissertations. Finally, the theme "thinking education and learning strategies" was most frequently studied in 2014 as postgraduate thesis and 2012 as doctorate thesis, and this theme was most frequently studies in Çukurova University as postgraduate thesis and in Y1ldı Technical University as doctorate thesis.

At this point, it can be stated that the tendency towards studying the "Curriculum", "Approach, strategy, and method", "attitude and value education" and "Thinking education and learning strategies" themes in branches of Curriculum and Instruction in Turkey is higher. In studies carried out by Saracaloğlu and Dursun (2010), Bıkmaz et al. (2013), Gömleksiz and Bozpolat (2013), Ozan and Köse (2014), and Kozikoğlu and Senemoğlu (2015) on theses and articles in branches of Curriculum and Instruction, it was concluded that the frequently studied themes were "learning-teaching approach, model, method, and techniques" and "curriculum development and assessment”.

289 academicians working in branches of Curriculum and Instruction and 729 lectures were examined in order to analyze the lectures and academicians from thematic aspect, and the findings were discussed.

Given the results obtained for the academicians working at 28 universities examined, it was determined that the universities employing highest number of academicians were Gazi, Middle East Technical, and Hacettepe Universities, respectively. The higher number of academicians employed in these universities is directly proportional to the fact that these universities are deep-rooted and successful ones. This finding is also in accord with data of General Ranking of State Universities (URAP, 2016). According to URAP (2016), Middle East Technical University is the best university in Turkey, whereas Hacettepe University is second best and Gazi University is 8th best university. Given the distribution of research assistants, it can be seen that the university employing highest number of research assistants is Middle East Technical University (13.8\%), followed by Ankara University (9.6\%) and Hacettepe University (9.6\%). This might be because these universities are the Scholar Education Program (ÖYP) Postgraduate Education Universities.

In Turkey, there are totally 729 postgraduate lectures in branches of Curriculum and Instruction. The universities with the highest number of lectures were found to be Middle East Technical University, Düzce University, and Çanakkale University, respectively. On the other hand, the universities with the lowest number of lectures were determined to be Ankara University, Hacettepe University, and Gaziosmanpaşa University. It was also observed that the number of personnel and the number of lectures were not in parallel with each other. For instance; even though Düzce University has the lowest number of academicians in Turkey, it is also one of the universities with highest number of lectures. Similarly, even though Hacettepe University is one of the universities with highest number of academic personnel, it is one of the universities with lowest number of lectures. This may be because of the difference between the numbers of elective lectures.

The postgraduate lectures were grouped under 14 main themes named Scientific Research, Education of Thinking, Educational Researches, Basics of Educational Curricula, Problems in Education, Types of Education, Management in Education, New Approaches in Education, Statistics, Basics of Teaching and Learning, Educating the Teachers, Measurement and Assessment, Curriculum, and Project Development. Curriculum, Basics of Learning and Teaching, and Basics of Curricula are the common themes given in all of the universities. In every university, there are lectures related with these themes. Thinking education, Project development, and Educational researches are the themes with minimum lectures in curricula. This may be because the lectures covered by the themes Curriculum, Basics of Learning and Teaching, and Basics of Curricula are the compulsory ones but those covered by themes Thinking education, Project development, and 
Educational researches are the elective lectures. Since they are the elective ones, not all of the universities offer these options.

It was determined that the lectures given within the scope of theme "curriculum" in branches of Curriculum and Instruction is "Curriculum development" and "Curriculum assessment". From a general perspective, the "curriculum development" incorporates designing, implementing, assessing, and re-adjusting the curricula. From this aspect, the effort to ensure continuous update is necessary (Erden, 1993). Significant advances have been achieved especially from the curriculum development efforts made within the body of Ministry of National Education in last decade. Thus, the lectures on curriculum development are still important.

Following the theme "curriculum", the second most frequently studied theme in branches of Curriculum and Instruction is the theme "Basics of learning and teaching". This theme is divided into 5 subthemes. Accordingly, it was determined that the most frequently lectured courses are "Approach", "Design", "Basics of Learning and Teaching", "Method and Technique", and "Informatics". Since 2005, the constructivist educational approach has been in practice in Turkey. However, the new curricula seem to have certain problems in practice (Turan, 2006; Boydak, 2008; Sünbül, 2010). Since there still are necessities regarding the curriculum approaches, these aspects should be given required importance. Thus, the universities are expected to have higher number of lectures under the theme "approach".

In the present study, the 28 universities' terms of acceptance to and graduation form postgraduate and doctorate programs in branches of Curriculum and Instruction were examined. The terms of acceptance were accepted as "ALES Score and Type of Score", "Foreign Language Score", "Department of Graduation", whereas the terms of graduation were determined to be "Number of lectures to pass", and "Grade Point Averages".

For applying to postgraduate and doctorate programs in branches of Curriculum and Instruction, $67.9 \%$ of universities set the minimum ALES score as 55. In a similar study carried out by Demirhan İşcan and Hazır B1kmaz (2012), it was emphasized that the minimum score for applying to postgraduate programs in branches of Curriculum and Instruction was 55. As the criterion for applying to postgraduate and doctorate programs, $62.5 \%$ of universities require Equal-Weighted ALES score. From the aspect of foreign language score, $35.7 \%$ of universities specified no limit for postgraduate programs, whereas $53.6 \%$ of universities set the lower limit to be 55 points for doctorate programs. In their study, Demirhan İşcan and Hazır Bıkmaz (2012) also reported the minimum score of foreign language to be 55 for applying to the doctorate programs. Given the criterion of graduation department for applying to programs in branches of Curriculum and Instruction, $46.4 \%$ of universities require the graduation from the faculty of education for postgraduate programs and $39.3 \%$ of universities require the graduation from Curriculum and Instruction postgraduate programs for applying to doctorate programs.

Examining the criteria for graduation from postgraduate and doctorate programs in branches of Curriculum and Instruction, it was found that the minimum number of lectures to pass is 7 for both postgraduate and doctorate programs $(73.2 \%)$. The grade point average necessary for passing to the phase of thesis was set to be minimum 2.00 by $46.4 \%$ of universities for graduation from postgraduate programs and minimum 2.50 by $37.5 \%$ of universities for graduation from doctorate programs.

\section{Recommendations}

In conclusion, certain topics in Curriculum and Instruction such as program model recommendations, variables affecting teacher's applications, interdisciplinary studies could be offered to analyze as doctorate dissertation. In addition, it could be stated that more qualitative studies, and mixed studies are necessary. Samples especially in other cities rather than big cities in Turkey could be offered to implement.

\section{References}

Bıkmaz et al., (2013). Eğitim programları ve öğretim alanında yapılan doktora tezlerine ait içerik

çözümlemesi (1974-2009). Eğitim ve Bilim Dergisi, 38 (168), 288-303.

Birinci, A. (1996). Üniversite ve Kitap, Türk Yurdu, 16(111).

Boydak, A. (2008). Yeni ögretim programlarına temel olan yaklaşımlar. İstanbul: Beyaz Yayınları.

Cohen, et al., (2007). Research Methods in Education. UK: Routledge, Taylor \&Francis Group.

Demirhan-İşcan, C. \& Hazır-Bıkmaz, F. (2012). Eğitim programları ve öğretim alanında 
lisansüstü eğitim programlarının analizi ve öneriler. Eğitim Bilimleri Fakültesi Dergisi, 45(1), 107-138.

Erdem, D. (2011). Türkiye'de 2005-2006 yılları arasında yayımlanan eğitim bilimleri

dergilerindeki makalelerin bazı özellikler açısından incelenmesi: Betimsel bir analiz. Eğitimde ve Psikolojide Ölçme ve Değerlendirme Dergisi, 2(1), 140-147.

Erden, M. (1993), Eğitimde Program Değerlendirme. Ankara: PEGEM Yayınları

Gömleksiz, M. N. \& Bozpolat, E. (2013). Eğitim programları ve öğretim alanındaki lisansüstü

Tezlerin değerlendirilmesi. The Journal of Academic Social Science Studies, 6(7), 457-472.

Gözütok, F. D. (1994). Ankara University eğitim bilimleri fakültesi programlarının

değerlendirilmesi. Ankara University Eğitim Bilimleri Fakültesi Dergisi, 27(2), 560-571.

Karakütük, K. (2002). Öğretim Üyesi Ve Bilim İnsanı Yetişstirme. Ankara: Anı Yayıncılık.

Kaya, S. (2014). Eğitim Programları ve Öğretimi Anabilim Dalı lisansüstü eğitimin değerlendirilmesi. International Journal of Human Sciences, 11(2), 802-826.

Kozikoglu, I., \& Senemoglu, N. (2015). The content analysis of dissertations completed in the field of curriculum and instruction (2009-2014). Education and Science, 40(182), 29-41.

Kurt, A. \& Erdoğan, M. (2015). Program değerlendirme araştırmalarının içerik analizi ve eğilimleri; 2004-2013 yılları arası. Eğitim ve Bilim Dergisi. 40(178), 199-224.

MEB (2012b). 12 Yıllık Zorunlu Eğitime Yönelik Uygulamalar. 30.05.2017 tarihinde http://www.meb.gov.tr/haberler/2012/12YillikZorunluEgitimeYonelikGenelge.pdf adresinden alınmıştır.

Mıhçıoğlu, C. (1989). Eğitim (bilimleri) fakültesinin kuruluşu üzerine. A.Ü. Eğitim Bilimleri Fakültesi Dergisi, 22(1), 347-391.

Ozan, C. \& Köse, E. (2014). Eğitim programları ve öğretim alanındaki araştırma eğilimleri. Sakarya University Journal of Education, 4(1), 116-136.

Özdemir, M. Ç., \& Arı, A. (2008). Eğitim programları ve öğretim bilim dalında yapılmış bazı doktora tezlerinin incelenmesi. H. Gümüs,, O. Ramazan, \& E. Esmer (Ed.), II. Lisansüstü Eğitim Sempozyum, 26-28 Eylül 2005: bildiriler kitabı (s. 40-63). İstanbul.

Özden, M. \& Ergin, B. (2013). Lisansüstü öğrencilerinin bilimsel araştırmalarda uygulanan etik kurallara yönelik düşüncelerinin belirlenmesi. Mustafa Kemal University Sosyal Bilimler Enstitüsü Dergisi, 10(22), 155-169.

Saracaloğlu, A. \& Dursun, F. (2010). Türkiye'de eğitim programları ve öğretim alanındaki lisansüstü tezlerin incelenmesi. 1. Ulusal Eğitim Programları ve Öğretim Kongresi Tam Metinler Kitabı. Ankara: Pegem Akademi.

Semerci, Ç. \& Meral, E. (17-20 Ekim 2007). Lisansüstü eğitimde program değerlendirmeye ilişkin tezlerin meta değerlendirmesi. (Fırat University örneği). Eskişehir: Lisansüstü Eğitim Sempozyumu.

Senemoğlu, N. (1991). A study of initial primary teacher training in England with implications for the system in Turkey. Yayımlanmamış araştırma raporu, Leicester: The University of Leicester.

Sünbül, A. M. (2010). Öğretim ilke ve yöntemleri. (4. baskı). Konya: Eğitim Akademi

Yayınları

Turan, M. (2006). Yeni ilköğretim programları. Gürol, M. (Ed.). Öğretimde planlama ve değerlendirme. (4.baskı). Ankara: Akış Yayıncılık.

Tuzcu, G. (2003), “Lisansüstü öğretim için yurtdışna öğrenci göndermenin planlanması”, Milli Eğitim Dergisi, ss.155-165. 
Türkiye Bilimler Akademisi (2001). Bilim Adamı Yetiştirme Lisansüstü Eğitim Ankara: TUBİTAK Matbaası.

URAP (2016). Devlet Üniversiteleri Genel Sıralaması. Erişim tarihi: 22 Mayıs 2017, http://tr.urapcenter.org/2015/2015_t5.php.

Varış, F. (1972). Türkiye'de Lisansüstü Eğitim: Pozitif Bilimlerin Temel ve Uygulamalı Alanlarında. Ankara: Ankara University Eğitim Fakültesi Yayınları.

Varış, F. (1989). Eğitimde program geliştirmeye sistematik yaklaşım. Ankara University Ĕgitim Bilimleri Dergisi. 22(1), 7-12.

Yapıcıŏlu et al., . (2015). Türkiye'de program değerlendirme çalışmalarında eğilimler ve sorunlar: alan uzmanlarının gözüyle. Uluslararası Eğitim Programları ve Öğretim Çalışmaları Dergisi, 6(12).

Yıldırım, A. \& Şimşek, H. (2011). Sosyal Bilimlerde Nitel Araştırma Yöntemleri. Ankara: Seçkin Yayıncılık. 